\title{
Sibling RivalRY in EdUCATIONAL ATTAINMENT: The German CASE*
}

\author{
by \\ Thomas Bauer \\ IZA, Bonn and CEPR, London \\ and \\ Ira N. Gang \\ Rutgers University
}

July 2000

Corresponding authors:

Ira N. Gang

Economics Department

Rutgers University

75 Hamilton St

New Brunswick NJ 08901-1248 USA

Tel.: +1 732 932-7405

Email: gang@economics.rutgers.edu
Thomas Bauer

IZA

P.O. Box 7240

D-53072 Bonn, Germany

Tel.: +492283894305

Email: bauer@iza.org

* We thank Rob Euwals, Melanie Ward and conference participants at the $3^{\text {rd }}$ International GSOEP User Conference, Berlin, July 1-3, 1998, and workshop participants at Bar Ilan University, Hebrew University, and Hunter College for their comments on earlier versions of this paper. Part of this paper was written while Thomas Bauer was visiting Rutgers University under the auspices of a Feodor Lynen Fellowship of the Alexander von Humboldt Foundation. Part of this paper was written while Ira Gang was visiting IZA, Bonn. 


\title{
Sibling RivalRY in EdUCATIONAL ATTAinMENT: The German CaSe
}

\begin{abstract}
Recent studies exploring sibling rivalry in the allocation of household resources in the U.S. produce conflicting results. We contribute to this discussion by addressing the role of sibling rivalry in educational attainment in Germany. Using the German Socioeconomic Panel (GSOEP) we are able to distinguish how the effects of sibling rivalry vary by cultural affiliation, i.e., among families of West German, East German and foreign origin. We also point out and correct for a reference group problem in earlier papers analyzing sibling rivalry.
\end{abstract}

JEL Classifications: J240, J160, I210, J15

Keywords: education, gender, sex composition, human capital formation, ethnicity, minorities 


\section{Introduction}

Recent articles have re-explored the issue of sibling rivalry in the allocation of household resources. Butcher and Case (1994), using the 1985 wave of the Panel Study of Income Dynamics, find that female educational attainment in the U.S. has been systematically affected by the sex composition of siblings, while male choices have not. Their estimations show that women who grew up with a sister received less education than women raised only with brothers. However, using the 1993 wave of the National Longitudinal Survey of Youth, Kaestner (1997) finds for whites and Hispanics that educational attainment is independent of sibling sex composition. He reveals that both black teenagers between the ages of 15 and 18 and black adults who grew up with a sister receive more education than those without a sister. Hausner and Kuo (1998) using three large U.S. surveys, the 1973 Occupational Change in a Generation Survey, the 1986 and 1998 Surveys of Income and Program Participation, and the 1989 National Survey of Families and Households, find negative effects of the number of siblings on educational attainment, whereas they find no evidence that sibling sex composition affects educational attainment among women. As Hausner and Kuo (1998) point out, the research on subgroups has found few consistent findings beyond the overall negative effect of the number of siblings. Taking these three studies together, sibling sex composition effects in educational outcomes seem to have declined over the last four decades in the U.S.

We contribute to this discussion by examining the role of sibling rivalry in educational attainment in Germany. Using the German Socioeconomic Panel (GSOEP) we are able to distinguish how the effects of sibling rivalry vary by cultural affiliation, i.e., among families of West German, East German and foreign origin. Compared to the United States, education in Germany is less costly and 
more standardized. This allows us to analyze sibling size and composition effects in a situation in which the household budget constraint is less binding. However, we expect differences between West German, East German and foreign households. The East German system provided a highly standardized and subsidized curriculum. Even though the children of guest-workers are required, under German law, to attend school, studies of educational attainment by different ethnic groups in Germany indicate that they are less intense in their school-going than their comparable German cohort, and that they leave school earlier (see Gang and Zimmermann, 2000). Hence, foreign households need to be differentiated from native West and East German households.

Section II briefly reviews some theoretical explanations of sibling rivalry in the allocation of scarce household resources. Section III describes the data set and the empirical strategy. In Section IV we discuss the estimation results and compare them to existing U.S. studies. Section V concludes.

\section{Theoretical Framework}

Economic explanations of sibling rivalry in the allocation of household resources for education are largely based on theoretical models of household behavior developed by Becker and Tomes $(1979,1986)$ and Becker $(1991) .{ }^{1}$ A major role in the derivation of sibling effects on educational attainment is played by the budget constraint of the household. If the budget constraint is not binding, parents invest until the rate of return of each child's education is equal to the market rate of interest and the education of each child in the family is independent of the size and the composition of its

\footnotetext{
Kaestner (1997) provides a survey of the economics literature. Strauss and Thomas (1995) survey related literature in development economics. Hausner and Kuo (1998) provide a broader survey which includes the sociological and demographic literature.
} 
siblings. However, where parents cannot finance the unconstrained optimal level of education for each child, household resources are allocated to those children with the highest rate of return to human capital investments. This makes the education of each child in the family dependent on the size and composition of its siblings. Additional siblings lower the available resources per child. If, for example, the rate of return to education is higher for men than for women, boys will receive a greater share of the household resources available for investment in education and will therefore have higher levels of educational attainment than females. Theory further predicts that when the return to education is higher for men than for women, a girl with only sisters will receive more education than a girl with brothers and that a boy with only brothers will receive less education than a boy with at least one sister.

In general, schooling in Germany, both East and West, is freely provided by the state. The costs of sending children to school consist of the living costs and time costs and, for children above age of sixteen, the opportunity costs of not working. For poor families the German government even pays the parents a subsidy for living costs, called BAföG. Hence, the costs of obtaining schooling in Germany is lower than obtaining schooling in the US and the budget constraint for sending children to school could be expected to be binding for less households in Germany if compared to the US . If parents do not have a strong aversion to earnings inequality among their children and if the rate of return to education is higher for men than for women, boys in Germany will receive more education than girls. ${ }^{2}$ Without a binding budget constraint, however, there should be no sibling

2 Behrman, Rosenzweig and Taubman (1994) present empirical evidence that parents do not have a strong aversion to earnings inequality and invest in children in ways which reinforce differences in innate earnings ability. Kaestner (1994) points out that analogous reasoning holds for differences in social environmental factors that influence earnings (i.e., gender discrimination). 
composition or sibling size effects.

If parents do have a strong aversion to earnings inequality and therefore allocate household resources so as to minimize earnings inequality among their children, children with relatively low returns to human capital investments will receive relatively more resources than children with high returns. If the budget constraint is also binding, a girl with only sisters will receive fewer resources than a girl with brothers, and boys will receive more education if they grow up in a family with only male children (Becker and Tomes, 1979, 1986; Behrman, Pollak, and Taubman, 1982).

Another source of sibling sex composition effects on educational attainment are the differences in the costs of raising boys and girls, such as different costs with respect to human capital investments (see Butcher and Case, 1994; Strauss and Thomas, 1995). Here, the educational attainments of male and female children depend on their relative percentage in the household. For example, in some cultures, the parents pay the marriage costs of their daughters. If the parents have to save for their daughters' marriages, fewer resources are then available for educational purposes. On the other hand, if a daughter's higher education increases the probability that she finds a rich husband, parents will allocate more resources to the education of their daughters. Again, these effects are only relevant when the household budget constraint for financing child education is binding.

Sibling sex composition effects may arise because different sibling sex compositions result in differences in the amount of gender specific traits that a child acquires (Butcher and Case, 1994). For example, if classroom instruction favors masculine traits, females (males) who grow up with older brothers (sisters) will receive more (less) education than females (males) who grow up only with older sisters (brothers). Butcher and Case (1994) also hypothesize that the sex composition of children alters the preferences of parents: "Parents with only one daughter may measure her 
achievements on the same scale used to measure their sons' and may provide her with an equal share of the households' educational resources. [...] When a second daughter enters the household, a daughter's reference group may change. Parents may group the daughters together and apply a different standard for homework, grades, and course loads." (Butcher and Case, 1994, p. 536). According to this theory, a girl with only brothers will receive more education than girls with at least one sister.

In summary, the literature provides several explanations for a sibling sex composition effect on educational attainment. The direction of this effect is ambiguous. Moreover, competing theories have similar predictions regarding the direction of any effect. These factors make deriving a priori testable hypotheses difficult. Common to most of these theories, however, is the role of the household budget constraint, i.e. sibling size and composition effects are only important when the household budget constraint is binding.

\section{Sample Description and Empirical Strategy}

We employ the 1996 wave of the German Socioeconomic Panel (GSOEP), a comprehensive panel

of household and individual data. Collection in West Germany began in 1984; in East Germany, in 1990. We look at a sample of individuals whose parents are also in the GSOEP. This provides us with a rich data set of individuals, with information on parents, number of siblings, sex of siblings, age of siblings, and so on. We restrict our sample to individuals aged between 17 and 46 who have completed their education (including formal occupational training), with at least one sibling and for whom information on their mother is available.

We are interested in contrasting the behavior of West Germans, East Germans and foreigners 
living in Germany. ${ }^{3}$ Following Butcher and Case (1994), Kaestner (1997) and Hausner and Kuo (1998) we regress educational attainment as measured by the years of schooling of an individual, on variables indicating the number of siblings and sibling sex composition within a family. As in Butcher and Case (1994) and Kaestner (1997), our measures of sibling sex composition consist of dummy variables indicating the presence of any sisters, the presence of any brothers, and the proportion of female children in the family. As we discussed in Section II, the percentage of female children in the family identifies whether the costs of raising daughters and sons systematically differ from each other.

We control for possible cohort effects by including the respondent's age and age-squared, and household income at the time the respondent was a child (proxied by the years of schooling of the mother and the father and dummy variables indicating the occupational status of the father). Since our sample includes households with missing fathers, we introduced a dummy variable that takes on the value of one if information on the father is available and further interact this dummy variable with all variables describing the characteristics of a father. We control for personal and family background characteristics by including variables indicating religious affiliation of the mother, whether one parent died before the respondent's 14th birthday, and whether the children support their parents by paying them money or looking after them in their own household. The latter controls for the possibility that parents invest more in one child because it expects this child to support them when they are old.

3 The GSOEP is available in two versions: a German version only available for use inside Germany and international version available worldwide. We use the international version, which is a $95 \%$ sample of the German version. In addition, some variables available in the German version are not available in the international version. For example, we do not have information on the nationality of the foreigners. However, we do know that in 1996 , of the 2170 foreigners in the GSOEP, 36\% were Turkish, 20\% Yugoslavian, 12\% Greek, 17\% Italian, and 6\% Spanish. 
We also include several variables describing the size and the structure of the sibling relationships of an individual. These include the number of siblings and the number of siblings-squared, a variable indicating the birth-order of the individual, and a variable measuring the birth distance, defined as the number of years between the birth of the respondent and the birth of the next older sibling. Descriptive statistics for the variables used in the analysis are reported in Table 1 of the Appendix.

\section{Estimation Results}

The empirical evidence on the relationship between sibling sex composition and educational attainment in the U.S. and Germany is summarized in Table $1 .^{4}$ The empirical evidence for the U.S. is mixed. Butcher and Case (1994) find a marginally significant negative effect for the presence of sisters and a marginally significant positive effect of the presence of brothers on the education of females. Kaestner (1997) finds a significant positive effect for the proportion of sisters in the family only on the education of black males and a positive effect for the presence of sisters only on the education of black females. Replicating their work for Germany, our estimations show a marginally significant positive effect of the presence of brothers on the education of West German males and a marginally significant negative effect of the presence of brothers on the education of foreign females. ${ }^{5}$ The percentage of female siblings appears to be negatively related to the education of foreign males and positively related to the education of foreign females, where the former coefficient is statistically significant at the 5 percent level and the latter at the 10 percent level. These results

\footnotetext{
4 The full set of estimation results for Germany is available on request.

5 For a detailed discussion of the replication issues confronted here, see Bauer and Gang (1999).
} 
indicate that for foreign families in Germany the costs of raising a son are higher than those of raising a daughter.

Sibling size effects on educational attainment are reported in Table 2. Butcher and Case (1994) use the number of siblings and the number of siblings squared, while Kaestner (1997) uses a series of dummy variables indicating the number of siblings. We replicate both using the GSOEP. Butcher and Case (1994) and Kaestner (1997) and others (see Hausner and Kuo (1998)) find significant sibling size effects -- the more siblings, the lower ones educational attainment. Even though our German results follow this pattern, they are only significant for West German males and foreign females. The lack of overall significance here and in the sibling composition effects are an indication that the budget constraint is not binding in Germany. This interpretation is supported by the result that we find only significant sibling size and composition effects when the proxies for household income are statistically significant.

The specifications used in Tables 1 and 2 are problematic when interpreting the coefficient on the dummy variable 'any sisters' or 'any brothers'. We illustrate this in Table 3, which provides possible examples of for the gender compositions of households and the reference group for the dummy variable coefficient. There is no problem as long as all the siblings (other than the respondent) are of the same sex. The last row of the Table indicates however that the reference group is ambiguous if the siblings are not of the same sex.

We handle this reference group problem by estimating separate regressions for households where there are two children (the respondent and one sibling) and for households where there are more than 
2 siblings. For two child households, clearly we drop the variable number of siblings ${ }^{6}$, and only use the dummy variable only sisters (the reference group is only brothers). For households with more than two children, we include sibling size variables and, to capture the gender composition effects unambiguously, the dummy variables 'only brothers' and 'only sisters'. These results are presented in Table 4.

For two child households there are no gender composition effects of educational attainment. For households with more than two children we find significant sibling size effects for West German males and females. Having only brothers does not affect anyone's educational attainment (relative to having both brothers and sisters), while having only sisters (relative to having both brothers and sisters) lowers the educational attainment of West German males and raises the educational attainment of foreign females. These larger households behave differently to smaller ones, and we observe somewhat different behavior than previously observed in Table 1.

With mild exceptions we can say that our overall results indicate that sibling size and sibling composition effects are not significant in determining educational attainment. Particularly interesting are the results for East Germany. In Table 4 the adjusted R-squared for East Germany is very high. In the estimations this very high R-squared is accounted for almost completely by age -- all the other variables were insignificant. ${ }^{7}$ For those raised in the East German educational system, educational attainment exhibits a cohort effect -- more recent cohorts have more, earlier cohorts have less education. These results indicate that for individuals raised in East Germany, the schooling decision that parents make for their children is completely unconstrained.

6 Recall, that we restricted our sample to households with at least one sibling.

7 See Appendix Table 3, available on request. 
There are several econometric issues that we have so far not addressed (and that the existing literature does also not address). First, our sample consists of people who have at least one sibling (that is, two children in the household). In other words, we ask "What is the effect of sibling size when moving from a one child household to a two-child household?". ${ }^{8}$ In unreported results we find a mild negative effect. Second, parents may make the choice of education and the choice of number of children simultaneously. We tried constructing several instruments for parents' choice of the number of children. All failed standard tests for good instruments (Bound, Baker, and Jaeger, 1995), and all raised our standard errors. Third, some argue that less talented parents have more children and provide them with less education, and that this may affect our results. Our feeling is that this and other related issues, if we were able to properly account for them, would just raise the standard errors and hence reinforce the result that, generally, gender and the number of siblings make no difference in educational attainment in Germany.

\section{Summary}

We estimate sibling sex composition and sibling size effects on the educational attainment for three groups of different cultural affiliation in Germany, i.e., West German, East German and foreign families, and compare the results with the existing empirical evidence for the U.S. Using the 1996 wave of the GSOEP, we regress an individual's years of schooling on different indicators of sibling sex composition and sibling size, family background, and person specific characteristics. We are careful in accounting for the relevant reference group, enabling us to more easily interpret our

\footnotetext{
8 Obviously there is no gender composition effect in a one child household.
} 
coefficients. The estimation results indicate that educational attainment in Germany is independent of the sibling sex composition. This is consistent with U.S. results. There are two exceptions. For West German males we find a significant negative effect of the presence of only sisters for households with more than two children, and for foreign females we find a significant positive effect of the presence of only sisters in the family. However, unlike the results for the U.S., we do not find significant sibling size effects (again with two exceptions -- West German males and foreign females).

Our findings are consistent with a story that says that household budget constraints do not matter for the allocation of resources for human capital investments among children. They are partly consistent with a story in which budget constraints matter, but the return to education is the same for men and women. In this case there would be no sibling sex composition effects, but we would expect to see a sibling size effect. The unimportance of a budget constraint is especially clear in the East German case.

These results are consistent with patterns observed in studies using more recent U.S. data, which find smaller or no composition effects, while larger effects are found in studies using less recent data. For developing countries, sibling composition effects are regularly found (see Strauss and Thomas (1995) and Garg and Morduch (1999)). It may well be that as incomes increase and education is more freely and cheaply available, gender effects and size effects disappear. Indeed, this is what the “ordering” of our results tell us. In East Germany, the opportunity cost of education was lowest, and we observe a highly educated society with little differentiation by gender. In West Germany, among the West Germans, the opportunity cost of education was low and we do observe some, but very little, differentiation. Among the guest-worker population in West Germany, education had a higher 
12

opportunity cost - the budget constraints were more binding - and we observe additional differentiation. 


\section{References}

Bauer, Thomas and Ira N. Gang. 1999. "Siblings, Their Sex Composition and Educational Attainment in Germany," DIW-Vierteljahrshefte (Quarterly Journal of Economic Research), 2-99: 215-221.

Becker, Gary S. 1991. A Treatise on the Family. Cambridge, MA: Harvard University Press.

Becker, Gary S., and Nigel Tomes. 1979. "An Equilibrium Theory of the Distribution of Income and Intergenerational Mobility." Journal of Political Economy 87 (December): 1153-89.

Becker, Gary S., and Nigel Tomes. 1986. "Human Capital and the Rise and Fall of Families" Journal of Labor Economics 4 (July): S1-S39.

Behrmann, Jere R., Robert A. Pollak, and Paul Taubmann. 1982 "Parental Preferences and Provision for Progeny." Journal of Political Economy 90 (February): 52-73.

Behrmann, Jere R., Mark R. Rosenzweig, and Paul Taubmann. 1994. "Endowments and the Allocation of Schooling in the Market: The Twins Experiment?" Journal of Political Economy 102 (December): 1131-74.

Bound, John, Regina M. Baker, and David A. Jaeger. 1995. "Problems with Instrumental Variables Estimation when the Correlation between the Instrument and the Endogenous Explanatory Variable Is Weak." Journal of the American Statistical Association, Vol. 90 (June): 443-50

Butcher, Kristin F. and Anne Case. 1994. "The Effect of Sibling Sex Composition on Women's Education and Earnings." Quarterly Journal of Economics 109 (August): 531-63.

Gang, Ira N. and Klaus F. Zimmermann. 2000. "Is Child Like Parent? Educational Attainment and Ethnic Origin." Journal of Human Resources, forthcoming.

Garg, Ashis and Jonathan Morduch. 1998 "Sibling Rivalry and the Gender Gap: Evidence from Child Cealth Outcomes in Ghana." Journal of Population Economics 11 (4):

Hauser, Robert M. and Hsiang-Hui Daphne Kuo. 1998. "Does the Gender Composition of Sibships Affect Women's Educational Attainment?" Journal of Human Resources 33 (Summer): 644657.

Kaestner, Robert. 1997. "Are Brothers Really Better? Sibling Sex Composition and Educational Achievement Revisited." Journal of Human Resources 32 (Spring): 250-84.

Strauss, John A., and Duncan Thomas. 1995. "Human Resources: Empirical Modeling of Household and Family Decisions.” In Handbook of Development Economics, Vol. 3, eds. T.N. Srinivasan 
and Jere Behrman, 1883-2023. New York and Oxford: Elsevier Science, North Holland. 
Table 1:

The Effect of Sibling Sex Composition on Educational Attainment: Regression Coefficients from Various Studies

\begin{tabular}{|c|c|c|c|c|c|}
\hline & & Any Sisters & Any Brothers & $\begin{array}{l}\text { Percentage of } \\
\text { female siblings } \\
\text { (incl. respondent) }\end{array}$ & Observations \\
\hline \multicolumn{6}{|l|}{ Butcher and Case (1994) } \\
\hline \multirow{2}{*}{\multicolumn{2}{|c|}{ Male }} & 0.052 & 0.094 & -0.123 & 1816 \\
\hline & & $(0.146)$ & $(0.155)$ & $(0.251)$ & \\
\hline \multirow{2}{*}{\multicolumn{2}{|c|}{ Female }} & $-0.302^{\dagger}$ & $0.227^{\dagger}$ & -0.399 & 2010 \\
\hline & & $(0.134)$ & $(0.134)$ & $(0.220)$ & \\
\hline \multicolumn{6}{|l|}{ Kaestner (1997) } \\
\hline \multirow[t]{6}{*}{ Male } & White & -0.101 & 0.028 & -0.214 & 4212 \\
\hline & & $(0.121)$ & $(0.120)$ & $(0.204)$ & \\
\hline & Black & 0.168 & 0.069 & $0.771^{\dagger \dagger}$ & 4212 \\
\hline & & $(0.190)$ & $(0.185)$ & $(0.279)$ & \\
\hline & Hispanic & 0.068 & -0.181 & -0.168 & 4212 \\
\hline & & $(0.217)$ & $(0.249)$ & $(0.351)$ & \\
\hline \multirow[t]{6}{*}{ Female } & White & -0.086 & 0.071 & 0.076 & 4271 \\
\hline & & $(0.119)$ & $(0.123)$ & $(0.202)$ & \\
\hline & Black & $0.333^{\dagger}$ & 0.174 & -0.059 & 4271 \\
\hline & & $(0.191)$ & $(0.192)$ & $(0.284)$ & \\
\hline & Hispanic & -0.276 & -0.315 & 0.110 & 4271 \\
\hline & & $(0.219)$ & $(0.232)$ & $(0.345)$ & \\
\hline \multicolumn{6}{|l|}{ Bauer and Gang } \\
\hline \multirow[t]{6}{*}{ Male } & West German & -0.059 & $0.313^{\dagger}$ & -0.297 & 1067 \\
\hline & & $(0.160)$ & $(0.163)$ & $(0.300)$ & \\
\hline & East German & -0.078 & 0.119 & -0.240 & 318 \\
\hline & & $(0.173)$ & $(0.161)$ & $(0.322)$ & \\
\hline & Foreigner & -0.280 & 0.269 & $-0.810^{\dagger \dagger}$ & 540 \\
\hline & & $(0.204)$ & $(0.209)$ & $(0.361)$ & \\
\hline \multirow[t]{6}{*}{ Female } & West German & -0.127 & 0.065 & -0.289 & 812 \\
\hline & & $(0.165)$ & $(0.171)$ & $(0.311)$ & \\
\hline & East German & -0.252 & 0.247 & -0.538 & 278 \\
\hline & & $(0.188)$ & $(0.201)$ & $(0.376)$ & \\
\hline & Foreigner & 0.190 & $-0.474^{\dagger}$ & $0.707^{\dagger}$ & 441 \\
\hline & & $(0.242)$ & $(0.249)$ & $(0.424)$ & \\
\hline
\end{tabular}

Source: Butcher and Case (1994), Table 5; Kaestner (1997), Table 5, Column (2) and (6), own estimations; standard deviations in parentheses. ${ }^{\dagger}$ : Statistical significant at least at the $10 \%$-level. ${ }^{\dagger}$ : Statistical significant at least at the 5\%-level. 
Table 2: The Effect of Sibling Size on Educational Attainment: Regression Coefficients from Various Studies

\begin{tabular}{|c|c|c|c|c|c|c|c|c|c|}
\hline & & Number of Siblings & Number of Siblings ${ }^{2}$ & Sibling $=2$ & Sibling $=3$ & Sibling $=4$ & Sibling $=5$ & $\begin{array}{c}\text { Sibling }=6 \\
\text { or more }\end{array}$ & Observations \\
\hline \multicolumn{10}{|l|}{ Butcher and Case (1994) } \\
\hline Male & & $\begin{array}{c}-0.507^{\dagger \dagger} \\
(0.079)\end{array}$ & $\begin{array}{l}0.027^{\dagger \dagger} \\
(0.007)\end{array}$ & - & - & - & - & - & 1816 \\
\hline Female & & $\begin{array}{c}-0.186^{\dagger \dagger} \\
(0.067)\end{array}$ & $\begin{array}{c}0.006 \\
(0.006)\end{array}$ & - & - & - & - & - & 2010 \\
\hline \multicolumn{10}{|l|}{ Kaestner (1997) } \\
\hline Male & & - & - & $\begin{array}{l}-0.207^{\dagger} \\
(0.114)\end{array}$ & $\begin{array}{c}-0.497^{\dagger \dagger} \\
(0.119)\end{array}$ & $\begin{array}{c}-0.684^{\dagger \dagger} \\
(0.131)\end{array}$ & $\begin{array}{c}-0.7744^{\dagger \dagger} \\
(0.143)\end{array}$ & $\begin{array}{c}-0.971^{\dagger \dagger} \\
(0.130)\end{array}$ & 4212 \\
\hline Female & & - & - & $\begin{array}{c}-0.015 \\
(0.112)\end{array}$ & $\begin{array}{c}-0.280^{\dagger \dagger} \\
(0.118)\end{array}$ & $\begin{array}{c}-0.318^{\dagger \dagger} \\
(0.126)\end{array}$ & $\begin{array}{c}-0.542^{\dagger \dagger} \\
(0.141)\end{array}$ & $\begin{array}{c}-0.594^{\dagger \dagger} \\
(0.127)\end{array}$ & 4271 \\
\hline Bauer and Gang & West German & $\begin{array}{l}-0.501^{\dagger \dagger} \\
(0.157)\end{array}$ & $\begin{array}{c}0.033 \\
(0.021)\end{array}$ & $\begin{array}{c}-0.092 \\
(0.178)\end{array}$ & $\begin{array}{c}-0.581^{\dagger \dagger} \\
(0.253)\end{array}$ & $\begin{array}{c}-1.156^{\dagger \dagger} \\
(0.354)\end{array}$ & $\begin{array}{c}-2.169^{\dagger \dagger} \\
(0.488)\end{array}$ & $\begin{array}{l}-0.660 \\
(0.635)\end{array}$ & 1067 \\
\hline & East German & $\begin{array}{l}-0.195 \\
(0.235)\end{array}$ & $\begin{array}{c}0.028 \\
(0.036)\end{array}$ & $\begin{array}{l}-0.116 \\
(0.203)\end{array}$ & $\begin{array}{l}-0.171 \\
(0.518)\end{array}$ & $\begin{array}{l}-0.225 \\
(0.501)\end{array}$ & $\begin{array}{c}1.711 \\
(1.075)\end{array}$ & $\begin{array}{c}0.094 \\
(0.842)\end{array}$ & 318 \\
\hline & Foreigner & $\begin{array}{l}-0.103 \\
(0.178)\end{array}$ & $\begin{array}{l}-0.014 \\
(0.021)\end{array}$ & $\begin{array}{c}0.052 \\
(0.219)\end{array}$ & $\begin{array}{l}-0.496^{\dagger} \\
(0.263)\end{array}$ & $\begin{array}{l}-0.300 \\
(0.316)\end{array}$ & $\begin{array}{l}-0.537 \\
(0.425)\end{array}$ & $\begin{array}{c}-1.280^{\dagger} \\
(0.410)\end{array}$ & 540 \\
\hline Female & West German & $\begin{array}{l}-0.247 \\
(0.173)\end{array}$ & $\begin{array}{c}0.029 \\
(0.023)\end{array}$ & $\begin{array}{c}-0.418^{\dagger \dagger} \\
(0.187)\end{array}$ & $\begin{array}{c}0.009 \\
(0.281)\end{array}$ & $\begin{array}{l}-0.058 \\
(0.398)\end{array}$ & $\begin{array}{l}-1.077^{\dagger} \\
(0.565)\end{array}$ & $\begin{array}{c}0.277 \\
(0.833)\end{array}$ & 812 \\
\hline & East German & $\begin{array}{c}0.294 \\
(0.292)\end{array}$ & $\begin{array}{l}-0.059 \\
(0.045)\end{array}$ & $\begin{array}{c}0.109 \\
(0.235)\end{array}$ & $\begin{array}{l}-0.352 \\
(0.426)\end{array}$ & $\begin{array}{c}0.566 \\
(0.544)\end{array}$ & $\begin{array}{c}-0.443 \\
(1.136)\end{array}$ & $\begin{array}{l}-0.726 \\
(0.913)\end{array}$ & 278 \\
\hline & Foreigner & $\begin{array}{l}-0.877^{\dagger \dagger} \\
(0.227)\end{array}$ & $\begin{array}{l}0.081^{\dagger \dagger} \\
(0.027)\end{array}$ & $\begin{array}{l}-0.668^{1 \dagger} \\
(0.274)\end{array}$ & $\begin{array}{c}-1.191^{\dagger \dagger} \\
(0.356)\end{array}$ & $\begin{array}{c}-1.824^{\dagger \dagger} \\
(0.402)\end{array}$ & $\begin{array}{l}-1.148^{\dagger \dagger} \\
(0.491)\end{array}$ & $\begin{array}{c}-1.198^{\dagger \dagger} \\
(0.552)\end{array}$ & 441 \\
\hline
\end{tabular}

Source: Butcher and Case (1994), Table 4, Columns (2) and (6); Kaestner (1997), Appendix Table B, Columns (6)-(9); own estimations; standard deviations in parentheses. ${ }^{\dagger}$ : Statistical significant at least at the $10 \%$-level. ${ }^{\dagger \dagger}$ : Statistical significant at least at the 5\%-level. 
Table 3: Sibling Sex Composition, Educational Attainment and Reference Group

\begin{tabular}{|c|c|c|c|c|c|c|c|c|c|c|c|c|}
\hline & & & & & & & & & & ale & & \\
\hline & West & erman & East C & erman & Fol & eign & West & Yerman & East & erman & Fol & ign \\
\hline & Children $=2$ & Children $>2$ & Children $=2$ & Children> & Children $=$ & Children> & Children $=2$ & Children $>2$ & Children $=$ & Children> & Children $=2$ & Children $>2$ \\
\hline Birth Order & -0.233 & 0.042 & -0.024 & -0.115 & 0.661 & $0.135^{\dagger}$ & -0.295 & -0.144 & -0.125 & 0.112 & 0.312 & -0.029 \\
\hline & $(0.293)$ & $(0.104)$ & $(0.287)$ & $(0.139)$ & $(0.486)$ & $(0.082)$ & $(0.312)$ & $(0.122)$ & $(0.315)$ & $(0.156)$ & $(0.673)$ & $(0.107)$ \\
\hline Birth Distance & 0.023 & 0.009 & 0.013 & $0.143^{\dagger \dagger}$ & 0.066 & 0.039 & -0.001 & $0.077^{\dagger}$ & -0.032 & 0.030 & 0.010 & 0.041 \\
\hline & $(0.050)$ & $(0.041)$ & $(0.049)$ & $(0.049)$ & $(0.095)$ & $(0.043)$ & $(0.054)$ & $(0.045)$ & $(0.046)$ & $(0.066)$ & $(0.152)$ & $(0.054)$ \\
\hline Number of Siblings & - & $-1.229^{\dagger \dagger}$ & - & 0.338 & - & -0.265 & - & -0.013 & - & 0.382 & - & $-0.640^{\dagger}$ \\
\hline & & $(0.292)$ & & $(0.597)$ & & $(0.283)$ & & $(0.323)$ & & $(0.681)$ & & $(0.350)$ \\
\hline Number of & - & $0.099^{\dagger \dagger}$ & - & -0.031 & - & 0.001 & - & 0.002 & - & -0.069 & - & $0.063^{\dagger}$ \\
\hline Siblings $^{2}$ & & $(0.031)$ & & $(0.071)$ & & $(0.030)$ & & $(0.034)$ & & $(0.084)$ & & $(0.038)$ \\
\hline Only Brothers & - & -0.129 & - & -0.083 & - & 0.307 & - & 0.311 & - & 0.339 & - & 0.199 \\
\hline & & $(0.274)$ & & $(0.451)$ & & $(0.267)$ & & $(0.275)$ & & $(0.352)$ & & $(0.326)$ \\
\hline Only Sisters & -0.108 & $-0.719^{\dagger \dagger}$ & -0.026 & -0.142 & -0.053 & -0.332 & 0.110 & -0.338 & -0.289 & 0.222 & 0.396 & $0.575^{\dagger}$ \\
\hline & $(0.202)$ & $(0.297)$ & $(0.187)$ & $(0.316)$ & $(0.345)$ & $(0.291)$ & $(0.217)$ & (0.299) & $(0.230)$ & $(0.518)$ & $(0.418)$ & $(0.346)$ \\
\hline $\mathrm{R}^{2}$ & 0.307 & 0.215 & 0.715 & 0.626 & 0.117 & 0.111 & 0.237 & 0.201 & 0.677 & 0.663 & 0.060 & 0.068 \\
\hline Observations & 531 & 536 & 197 & 121 & 127 & 413 & 402 & 410 & 177 & 101 & 127 & 314 \\
\hline
\end{tabular}


Appendix Table 1: Descriptive Statistics - Household Data

\begin{tabular}{|c|c|c|c|c|c|c|}
\hline & \multicolumn{3}{|c|}{ Male } & \multicolumn{3}{|c|}{ Female } \\
\hline & $\begin{array}{c}\text { West } \\
\text { German }\end{array}$ & $\begin{array}{c}\text { East } \\
\text { German }\end{array}$ & Foreign & $\begin{array}{c}\text { West } \\
\text { German }\end{array}$ & $\begin{array}{c}\text { East } \\
\text { German }\end{array}$ & Foreign \\
\hline Mother Catholic & 0.381 & 0.060 & 0.256 & 0.408 & 0.043 & 0.277 \\
\hline Mother Protestant & 0.417 & 0.283 & 0.019 & 0.403 & 0.299 & 0.016 \\
\hline Parent Died Before Age 14 & 0.021 & 0.022 & 0.006 & 0.022 & 0.029 & 0.009 \\
\hline \multirow[t]{2}{*}{ Mother's Years of Schooling } & 10.472 & 12.083 & 8.471 & 10.516 & 12.148 & 8.557 \\
\hline & $(1.805)$ & $(1.824)$ & $(1.874)$ & $(1.816)$ & $(1.853)$ & $(1.884)$ \\
\hline Information on Father Available & 0.908 & 0.893 & 0.956 & 0.927 & 0.885 & 0.948 \\
\hline \multirow[t]{2}{*}{ Father's Years of Schooling } & 9.402 & 10.868 & 8.724 & 9.481 & 10.608 & 8.755 \\
\hline & $(5.012)$ & $(4.601)$ & $(3.412)$ & $(4.810)$ & $(4.891)$ & $(3.581)$ \\
\hline Father Skilled Worker & 0.455 & 0.648 & 0.211 & 0.472 & 0.608 & 0.184 \\
\hline Father Worker: Other & 0.179 & 0.085 & 0.169 & 0.167 & 0.140 & 0.190 \\
\hline Payments to Parents & 0.027 & 0.028 & 0.013 & 0.022 & 0.018 & 0.020 \\
\hline \multirow[t]{2}{*}{ Age } & 28.619 & 24.868 & 27.165 & 26.889 & 23.464 & 26.045 \\
\hline & $(5.990)$ & $(6.092)$ & $(5.677)$ & $(5.671)$ & $(5.287)$ & $(5.248)$ \\
\hline \multirow[t]{2}{*}{ Birth-Order } & 2.096 & 1.821 & 2.402 & 2.078 & 1.856 & 2.231 \\
\hline & $(1.322)$ & (1.067) & (1.479) & (1.280) & $(1.027)$ & $(1.345)$ \\
\hline \multirow[t]{2}{*}{ Birth Distance } & 2.365 & 2.187 & 2.269 & 2.310 & 2.277 & 2.039 \\
\hline & $(2.881)$ & $(3.060)$ & $(2.457)$ & $(2.834)$ & $(3.137)$ & $(2.334)$ \\
\hline \multirow[t]{2}{*}{ Number of Siblings } & 1.986 & 1.638 & 2.801 & 1.929 & 1.612 & 2.651 \\
\hline & $(1.402)$ & $(1.065)$ & $(1.723)$ & $(1.298)$ & $(1.068)$ & $(1.680)$ \\
\hline Brother present & 0.688 & 0.569 & 0.767 & 0.672 & 0.673 & 0.780 \\
\hline Sister present & 0.658 & 0.667 & 0.780 & 0.639 & 0.572 & 0.698 \\
\hline \multirow[t]{2}{*}{ Proportion of Sisters (incl. respondent) } & 0.295 & 0.315 & 0.339 & 0.687 & 0.684 & 0.634 \\
\hline & $(0.241)$ & $(0.246)$ & $(0.223)$ & $(0.246)$ & $(0.240)$ & $(0.236)$ \\
\hline \multirow[t]{2}{*}{ Years of Schooling } & 11.166 & 10.035 & 9.860 & 10.660 & 9.631 & 9.752 \\
\hline & $(2.644)$ & $(2.342)$ & $(1.895)$ & $(2.375)$ & $(2.454)$ & $(2.145)$ \\
\hline Observations & 1067 & 318 & 540 & 812 & 278 & 441 \\
\hline
\end{tabular}

Notes: Standard deviation in parentheses.

Source: GSOEP (1996); own calculations. 
Appendix Table 2: Sibling Sex Composition

\begin{tabular}{|c|c|c|c|c|c|c|c|c|c|c|c|c|c|c|c|c|c|c|}
\hline \multirow[b]{3}{*}{ Constant } & \multicolumn{8}{|c|}{ Male } & \multicolumn{10}{|c|}{ Female } \\
\hline & \multicolumn{3}{|c|}{ West German } & \multicolumn{3}{|c|}{ East German } & \multicolumn{3}{|c|}{ Foreign } & \multicolumn{3}{|c|}{ West German } & \multicolumn{3}{|c|}{ East German } & \multicolumn{3}{|c|}{ Foreign } \\
\hline & $\begin{array}{l}-5.566^{\dagger \dagger} \\
(1.416)\end{array}$ & $\begin{array}{l}-5.465^{\dagger \dagger} \\
(1.417)\end{array}$ & $\begin{array}{l}-5.431^{\dagger \dagger} \\
(1.417)\end{array}$ & $\begin{array}{c}-11.967^{\dagger \dagger} \\
(1.356)\end{array}$ & $\begin{array}{c}-11.924^{\dagger \dagger}- \\
(1.355)\end{array}$ & $\begin{array}{l}-11.901^{\dagger \dagger} \\
(1.355)\end{array}$ & $\begin{array}{l}3.495^{\dagger \dagger} \\
(1.671)\end{array}$ & $\begin{array}{l}3.716^{\dagger \dagger} \\
(1.685)\end{array}$ & $\begin{array}{l}3.899^{\dagger \dagger} \\
(1.679)\end{array}$ & $\begin{array}{l}-1.219 \\
(1.469)\end{array}$ & $\begin{array}{l}-1.166 \\
(1.470)\end{array}$ & $\begin{array}{l}-0.961 \\
(1.495)\end{array}$ & $\begin{array}{c}-12.203^{\dagger \dagger} \\
(1.720)\end{array}$ & $\begin{array}{l}-12.152^{\dagger \dagger} \\
(1.717)\end{array}$ & $\begin{array}{c}-11.710^{\dagger \dagger} \\
(1.734)\end{array}$ & $\begin{array}{l}6.580^{\dagger \dagger} \\
(2.042)\end{array}$ & $\begin{array}{l}6.290^{\dagger \dagger} \\
(2.044)\end{array}$ & $\begin{array}{l}5.736^{\dagger 7} \\
(2.068)\end{array}$ \\
\hline Mother Catholic & $\begin{array}{l}1.137^{\dagger \dagger} \\
(0.195)\end{array}$ & $\begin{array}{l}1.145^{\dagger \dagger} \\
(0.195)\end{array}$ & $\begin{array}{l}1.146^{\dagger \dagger} \\
(0.195)\end{array}$ & $\begin{array}{l}-0.314 \\
(0.324)\end{array}$ & $\begin{array}{l}-0.327 \\
(0.328)\end{array}$ & $\begin{array}{l}-0.332 \\
(0.326)\end{array}$ & $\begin{array}{c}0.276 \\
(0.182)\end{array}$ & $\begin{array}{c}0.273 \\
(0.182)\end{array}$ & $\begin{array}{c}0.295 \\
(0.182)\end{array}$ & $\begin{array}{l}1.229^{\dagger} \\
(0.214)\end{array}$ & $\begin{array}{l}1.227^{\dagger \dagger} \\
(0.214)\end{array}$ & $\begin{array}{l}1.227^{\dagger \dagger} \\
(0.214)\end{array}$ & $\begin{array}{c}0.455 \\
(0.438)\end{array}$ & $\begin{array}{c}0.444 \\
(0.437)\end{array}$ & $\begin{array}{l}0.446 \\
(0.437)\end{array}$ & $\begin{array}{c}0.034 \\
(0.225)\end{array}$ & $\begin{array}{l}-0.005 \\
(0.226)\end{array}$ & $\begin{array}{l}-0.014 \\
(0.225)\end{array}$ \\
\hline Mother Protestant & $\begin{array}{l}1.189^{\dagger \dagger} \\
(0.191)\end{array}$ & $\begin{array}{l}1.193^{\dagger \dagger} \\
(0.191)\end{array}$ & $\begin{array}{l}1.194^{\dagger \dagger} \\
(0.191)\end{array}$ & $\begin{array}{l}-0.110 \\
(0.175)\end{array}$ & $\begin{array}{l}-0.113 \\
(0.176)\end{array}$ & $\begin{array}{l}-0.113 \\
(0.175)\end{array}$ & $\begin{array}{c}0.819 \\
(0.592)\end{array}$ & $\begin{array}{c}0.672 \\
(0.601)\end{array}$ & $\begin{array}{c}0.691 \\
(0.592)\end{array}$ & $\begin{array}{l}1.012^{\dagger \dagger} \\
(0.212)\end{array}$ & $\begin{array}{l}1.012^{\dagger \dagger} \\
(0.212)\end{array}$ & $\begin{array}{l}1.006^{\dagger \dagger} \\
(0.212)\end{array}$ & $\begin{array}{l}-0.059 \\
(0.193)\end{array}$ & $\begin{array}{l}-0.060 \\
(0.193)\end{array}$ & $\begin{array}{l}-0.061 \\
(0.192)\end{array}$ & $\begin{array}{l}2.487^{\dagger \dagger} \\
(0.790)\end{array}$ & $\begin{array}{l}2.403^{\dagger \dagger} \\
(0.792)\end{array}$ & $\begin{array}{l}2.459^{i \dagger} \\
(0.790)\end{array}$ \\
\hline Parent Died before Age 14 & $\begin{array}{c}0.136 \\
(0.520)\end{array}$ & $\begin{array}{c}0.118 \\
(0.521)\end{array}$ & $\begin{array}{c}0.125 \\
(0.521)\end{array}$ & $\begin{array}{l}-0.345 \\
(0.548)\end{array}$ & $\begin{array}{l}-0.368 \\
(0.547)\end{array}$ & $\begin{array}{l}-0.354 \\
(0.547)\end{array}$ & $\begin{array}{l}-1.732 \\
(1.136)\end{array}$ & $\begin{array}{l}-1.811 \\
(1.139)\end{array}$ & $\begin{array}{l}-1.889^{\dagger} \\
(1.135)\end{array}$ & $\begin{array}{c}0.080 \\
(0.539)\end{array}$ & $\begin{array}{c}0.087 \\
(0.538)\end{array}$ & $\begin{array}{c}0.066 \\
(0.538)\end{array}$ & $\begin{array}{c}0.181 \\
(0.569)\end{array}$ & $\begin{array}{c}0.155 \\
(0.569)\end{array}$ & $\begin{array}{c}0.155 \\
(0.569)\end{array}$ & $\begin{array}{l}-1.339 \\
(1.069)\end{array}$ & $\begin{array}{l}-1.266 \\
(1.072)\end{array}$ & $\begin{array}{l}-1.250 \\
(1.069)\end{array}$ \\
\hline Mother's Years of Schooling & $\begin{array}{l}0.256^{\dagger \dagger} \\
(0.042)\end{array}$ & $\begin{array}{l}0.257^{\dagger \dagger} \\
(0.042)\end{array}$ & $\begin{array}{c}0.258^{\dagger \dagger} \\
(0.042)\end{array}$ & $\begin{array}{c}0.083^{\dagger} \\
(0.047)\end{array}$ & $\begin{array}{l}0.084^{\dagger} \\
(0.047)\end{array}$ & $\begin{array}{c}0.083^{\dagger} \\
(0.047)\end{array}$ & $\begin{array}{c}0.016 \\
(0.046)\end{array}$ & $\begin{array}{c}0.013 \\
(0.046)\end{array}$ & $\begin{array}{c}0.013 \\
(0.046)\end{array}$ & $\begin{array}{c}0.073 \\
(0.045)\end{array}$ & $\begin{array}{c}0.074 \\
(0.045)\end{array}$ & $\begin{array}{c}0.073 \\
(0.045)\end{array}$ & $\begin{array}{l}-0.046 \\
(0.054)\end{array}$ & $\begin{array}{c}-0.046 \\
(0.054)\end{array}$ & $\begin{array}{l}-0.047 \\
(0.053)\end{array}$ & $\begin{array}{c}0.069 \\
(0.058)\end{array}$ & $\begin{array}{c}0.067 \\
(0.058)\end{array}$ & $\begin{array}{c}0.068 \\
(0.058)\end{array}$ \\
\hline Information on Father Available & $\begin{array}{c}0.304 \\
(0.330)\end{array}$ & $\begin{array}{c}0.274 \\
(0.331)\end{array}$ & $\begin{array}{c}0.289 \\
(0.331)\end{array}$ & $\begin{array}{c}0.530 \\
(0.440)\end{array}$ & $\begin{array}{c}0.534 \\
(0.440)\end{array}$ & $\begin{array}{c}0.530 \\
(0.440)\end{array}$ & & & & $\begin{array}{l}-0.135 \\
(0.377)\end{array}$ & & & $\begin{array}{l}-0.146 \\
(0.462)\end{array}$ & $\begin{array}{l}-0.102 \\
(0.461)\end{array}$ & $\begin{array}{l}-0.127 \\
(0.461)\end{array}$ & $\begin{array}{l}-0.234 \\
(0.582)\end{array}$ & $\begin{array}{l}-0.261 \\
(0.585)\end{array}$ & $\begin{array}{l}-0.228 \\
(0.583)\end{array}$ \\
\hline Father's Years of Schooling & $\begin{array}{l}-0.003 \\
(0.019)\end{array}$ & $\begin{array}{l}-0.001 \\
(0.019)\end{array}$ & $\begin{array}{l}-0.001 \\
(0.019)\end{array}$ & $\begin{array}{l}-0.027 \\
(0.030)\end{array}$ & $\begin{array}{l}-0.027 \\
(0.030)\end{array}$ & $\begin{array}{l}-0.026 \\
(0.030)\end{array}$ & $\begin{array}{c}0.021 \\
(0.030)\end{array}$ & $\begin{array}{c}0.022 \\
(0.030)\end{array}$ & $\begin{array}{c}0.019 \\
(0.030)\end{array}$ & $\begin{array}{l}0.033^{\dagger} \\
(0.020)\end{array}$ & $\begin{array}{l}0.034^{\dagger} \\
(0.020)\end{array}$ & $\begin{array}{l}0.033^{\dagger} \\
(0.020)\end{array}$ & $\begin{array}{c}0.039 \\
(0.029)\end{array}$ & $\begin{array}{c}0.037 \\
(0.029)\end{array}$ & $\begin{array}{c}0.038 \\
(0.029)\end{array}$ & $\begin{array}{c}0.049 \\
(0.036)\end{array}$ & $\begin{array}{c}0.052 \\
(0.036)\end{array}$ & $\begin{array}{c}0.051 \\
(0.036)\end{array}$ \\
\hline Father Skilled Worker & $\begin{array}{l}0.354^{\dagger \dagger} \\
(0.160)\end{array}$ & $\begin{array}{l}0.341^{\dagger \dagger} \\
(0.160)\end{array}$ & $\begin{array}{l}0.343^{\dagger \dagger} \\
(0.160)\end{array}$ & $\begin{array}{c}0.181 \\
(0.173)\end{array}$ & $\begin{array}{c}0.188 \\
(0.173)\end{array}$ & $\begin{array}{c}0.182 \\
(0.173)\end{array}$ & $\begin{array}{c}0.244 \\
(0.205)\end{array}$ & $\begin{array}{c}0.234 \\
(0.206)\end{array}$ & $\begin{array}{c}0.217 \\
(0.205)\end{array}$ & $\begin{array}{c}0.231 \\
(0.171)\end{array}$ & $\begin{array}{c}0.229 \\
(0.170)\end{array}$ & $\begin{array}{c}0.232 \\
(0.170)\end{array}$ & $\begin{array}{c}0.192 \\
(0.214)\end{array}$ & $\begin{array}{c}0.198 \\
(0.214)\end{array}$ & $\begin{array}{c}0.198 \\
(0.214)\end{array}$ & $\begin{array}{c}0.210 \\
(0.270)\end{array}$ & $\begin{array}{c}0.218 \\
(0.270)\end{array}$ & $\begin{array}{c}0.221 \\
(0.270)\end{array}$ \\
\hline Father Worker: Others & $\begin{array}{l}-0.108 \\
(0.217)\end{array}$ & $\begin{array}{c}-0.124 \\
(0.217)\end{array}$ & $\begin{array}{l}-0.121 \\
(0.217)\end{array}$ & $\begin{array}{c}0.537 \\
(0.326)\end{array}$ & $\begin{array}{c}0.535 \\
(0.326)\end{array}$ & $\begin{array}{c}0.537 \\
(0.326)\end{array}$ & $\begin{array}{l}-0.192 \\
(0.250)\end{array}$ & $\begin{array}{l}-0.174 \\
(0.250)\end{array}$ & $\begin{array}{l}-0.152 \\
(0.250)\end{array}$ & $\begin{array}{l}-0.043 \\
(0.242)\end{array}$ & $\begin{array}{l}-0.045 \\
(0.242)\end{array}$ & $\begin{array}{l}-0.037 \\
(0.242)\end{array}$ & $\begin{array}{c}0.411 \\
(0.322)\end{array}$ & $\begin{array}{c}0.410 \\
(0.321)\end{array}$ & $\begin{array}{c}0.404 \\
(0.321)\end{array}$ & $\begin{array}{l}-0.256 \\
(0.287)\end{array}$ & $\begin{array}{l}-0.206 \\
(0.287)\end{array}$ & $\begin{array}{l}-0.214 \\
(0.286)\end{array}$ \\
\hline Payments to Parents & $\begin{array}{c}-0.382 \\
(0.431)\end{array}$ & $\begin{array}{c}-0.384 \\
(0.432)\end{array}$ & $\begin{array}{l}-0.384 \\
(0.432)\end{array}$ & $\begin{array}{c}-0.574 \\
(0.466)\end{array}$ & $\begin{array}{l}-0.577 \\
(0.468)\end{array}$ & $\begin{array}{c}-0.601 \\
(0.470)\end{array}$ & $\begin{array}{c}-0.053 \\
(0.699)\end{array}$ & $\begin{array}{c}-0.078 \\
(0.700)\end{array}$ & $\begin{array}{l}-0.129 \\
(0.698)\end{array}$ & $\begin{array}{c}-0.330 \\
(0.508)\end{array}$ & $\begin{array}{l}-0.327 \\
(0.508)\end{array}$ & $\begin{array}{l}-0.330 \\
(0.507)\end{array}$ & $\begin{array}{l}1.329^{\dagger \dagger} \\
(0.667)\end{array}$ & $\begin{array}{l}1.392^{\dagger \dagger} \\
(0.665)\end{array}$ & $\begin{array}{l}1.379^{\dagger \dagger} \\
(0.665)\end{array}$ & $\begin{array}{c}0.100 \\
(0.691)\end{array}$ & $\begin{array}{c}0.124 \\
(0.695)\end{array}$ & $\begin{array}{c}0.106 \\
(0.692)\end{array}$ \\
\hline Age & $\begin{array}{l}0.761^{\dagger \dagger} \\
(0.087)\end{array}$ & $\begin{array}{l}0.760^{\dagger \dagger} \\
(0.088)\end{array}$ & $\begin{array}{l}0.759^{\dagger \dagger} \\
(0.087)\end{array}$ & $\begin{array}{l}1.333^{\dagger \dagger} \\
(0.084)\end{array}$ & $\begin{array}{l}1.332^{\dagger \dagger} \\
(0.084)\end{array}$ & $\begin{array}{l}1.332^{\dagger \dagger} \\
(0.084)\end{array}$ & $\begin{array}{l}0.334^{\dagger \dagger} \\
(0.113)\end{array}$ & $\begin{array}{l}0.331^{\dagger \dagger} \\
(0.113)\end{array}$ & $\begin{array}{l}0.323^{\dagger \dagger} \\
(0.113)\end{array}$ & $\begin{array}{l}0.603^{\dagger \dagger} \\
(0.095)\end{array}$ & $\begin{array}{l}0.603^{\dagger \dagger} \\
(0.095)\end{array}$ & $\begin{array}{l}0.6044^{+\dagger} \\
(0.095)\end{array}$ & $\begin{array}{l}1.402^{\dagger \dagger} \\
(0.109)\end{array}$ & $\begin{array}{l}1.403^{\dagger \dagger} \\
(0.109)\end{array}$ & $\begin{array}{l}1.404^{\dagger \dagger} \\
(0.109)\end{array}$ & $\begin{array}{c}0.216 \\
(0.138)\end{array}$ & $\begin{array}{c}0.224 \\
(0.138)\end{array}$ & $\begin{array}{c}0.223 \\
(0.138)\end{array}$ \\
\hline $\mathrm{Age}^{2}$ & $\begin{array}{r}-0.010^{\dagger \dagger} \\
(0.002) \\
\end{array}$ & $\begin{array}{c}-0.010^{\dagger \dagger} \\
(0.002) \\
\end{array}$ & $\begin{array}{c}-0.010^{\dagger \dagger} \\
(0.002) \\
\end{array}$ & $\begin{array}{l}-0.019^{\dagger \dagger} \\
(0.001) \\
\end{array}$ & $\begin{array}{c}-0.019^{\dagger \dagger} \\
(0.001) \\
\end{array}$ & $\begin{array}{l}-0.019^{\dagger \dagger} \\
(0.001)\end{array}$ & $\begin{array}{r}-0.004^{4 \dagger} \\
(0.002) \\
\end{array}$ & $\begin{array}{c}-0.004^{\dagger \dagger} \\
(0.002) \\
\end{array}$ & $\begin{array}{r}-0.004+\bar{\dagger} \\
(0.002) \\
\end{array}$ & $\begin{array}{l}-0.007^{\dagger \dagger} \\
(0.002) \\
\end{array}$ & $\begin{array}{r}-0.007^{7 \dagger} \\
(0.002) \\
\end{array}$ & $\begin{array}{r}-0.007^{\dagger \dagger} \\
(0.002) \\
\end{array}$ & $\begin{array}{c}-0.019^{\dagger \dagger} \\
(0.002) \\
\end{array}$ & $\begin{array}{l}-0.019^{\dagger \dagger} \\
(0.002) \\
\end{array}$ & $\begin{array}{r}-0.019^{\dagger \dagger} \\
(0.002) \\
\end{array}$ & $\begin{array}{l}-0.002 \\
(0.002) \\
\end{array}$ & $\begin{array}{l}-0.003 \\
(0.002) \\
\end{array}$ & $\begin{array}{l}-0.003 \\
(0.002) \\
\end{array}$ \\
\hline
\end{tabular}




\section{Table 2: Continued}

\begin{tabular}{|c|c|c|c|c|c|c|c|c|c|c|c|c|c|c|c|c|c|c|}
\hline \multirow[b]{3}{*}{ Birth Order } & \multicolumn{8}{|c|}{ Tale } & \multicolumn{10}{|c|}{ Female } \\
\hline & \multicolumn{2}{|c|}{ West German } & \multicolumn{4}{|c|}{ East German } & \multicolumn{2}{|c|}{ Foreign } & \multicolumn{4}{|c|}{ West German } & \multicolumn{2}{|c|}{ East German } & \multicolumn{4}{|c|}{ Foreign } \\
\hline & $\begin{array}{l}-0.033 \\
(0.096)\end{array}$ & $\begin{array}{l}-0.035 \\
(0.096)\end{array}$ & $\begin{array}{c}-0.033 \\
(0.096)\end{array}$ & $\begin{array}{l}-0.102 \\
(0.118)\end{array}$ & $\begin{array}{l}-0.101 \\
(0.119)\end{array}$ & $\begin{array}{l}-0.109 \\
(0.119)\end{array}$ & $\begin{array}{c}0.107 \\
(0.078)\end{array}$ & $\begin{array}{c}0.109 \\
(0.078)\end{array}$ & $\begin{array}{c}0.109 \\
(0.078)\end{array}$ & $\begin{array}{l}-0.186^{\dagger} \\
(0.113)\end{array}$ & $\begin{array}{l}-0.188^{\dagger} \\
(0.113)\end{array}$ & $\begin{array}{l}-0.186^{\dagger} \\
(0.113)\end{array}$ & $\begin{array}{c}0.031 \\
(0.135)\end{array}$ & $\begin{array}{c}0.033 \\
(0.135)\end{array}$ & $\begin{array}{c}0.027 \\
(0.135)\end{array}$ & $\begin{array}{c}0.013 \\
(0.106)\end{array}$ & $\begin{array}{c}0.006 \\
(0.107)\end{array}$ & $\begin{array}{c}0.014 \\
(0.106)\end{array}$ \\
\hline Birth Distance & $\begin{array}{c}0.016 \\
(0.029)\end{array}$ & $\begin{array}{c}0.015 \\
(0.029)\end{array}$ & $\begin{array}{c}0.015 \\
(0.029)\end{array}$ & $\begin{array}{l}0.068^{\dagger \dagger} \\
(0.031)\end{array}$ & $\begin{array}{l}0.068^{\dagger \dagger} \\
(0.031)\end{array}$ & $\begin{array}{l}0.069^{\dagger \dagger} \\
(0.031)\end{array}$ & $\begin{array}{c}0.071^{\dagger} \\
(0.036)\end{array}$ & $\begin{array}{l}0.071^{\dagger} \\
(0.036)\end{array}$ & $\begin{array}{l}0.069^{\dagger} \\
(0.036)\end{array}$ & $\begin{array}{c}0.022 \\
(0.032)\end{array}$ & $\begin{array}{c}0.022 \\
(0.032)\end{array}$ & $\begin{array}{c}0.022 \\
(0.032)\end{array}$ & $\begin{array}{l}-0.028 \\
(0.033)\end{array}$ & $\begin{array}{l}-0.025 \\
(0.033)\end{array}$ & $\begin{array}{l}-0.026 \\
(0.033)\end{array}$ & $\begin{array}{c}0.046 \\
(0.049)\end{array}$ & $\begin{array}{c}0.045 \\
(0.049)\end{array}$ & $\begin{array}{c}0.045 \\
(0.049)\end{array}$ \\
\hline Number of Siblings & $\begin{array}{c}-0.606^{\dagger \dagger} \\
(0.158)\end{array}$ & $\begin{array}{l}-0.501^{\dagger \dagger} \\
(0.157)\end{array}$ & $\begin{array}{c}-0.496^{\dagger \dagger} \\
(0.153)\end{array}$ & $\begin{array}{l}-0.254 \\
(0.231)\end{array}$ & $\begin{array}{l}-0.195 \\
(0.235)\end{array}$ & $\begin{array}{l}-0.184 \\
(0.233)\end{array}$ & $\begin{array}{l}-0.233 \\
(0.188)\end{array}$ & $\begin{array}{l}-0.103 \\
(0.178)\end{array}$ & $\begin{array}{l}-0.125 \\
(0.175)\end{array}$ & $\begin{array}{l}-0.298^{\dagger} \\
(0.174)\end{array}$ & $\begin{array}{l}-0.247 \\
(0.173)\end{array}$ & $\begin{array}{l}-0.307^{\dagger} \\
(0.170)\end{array}$ & $\begin{array}{c}0.118 \\
(0.295)\end{array}$ & $\begin{array}{c}0.294 \\
(0.292)\end{array}$ & $\begin{array}{c}0.131 \\
(0.290)\end{array}$ & $\begin{array}{c}-0.743^{\dagger \dagger} \\
(0.216)\end{array}$ & $\begin{array}{l}-0.877^{\dagger \dagger} \\
(0.227)\end{array}$ & $\begin{array}{c}-0.782^{\dagger \dagger} \\
(0.213)\end{array}$ \\
\hline Number of Siblings ${ }^{2}$ & $\begin{array}{l}0.042^{\dagger \dagger} \\
(0.021)\end{array}$ & $\begin{array}{l}0.033^{\dagger} \\
(0.021)\end{array}$ & $\begin{array}{l}0.033^{\dagger} \\
(0.020)\end{array}$ & $\begin{array}{c}0.033 \\
(0.036)\end{array}$ & $\begin{array}{c}0.028 \\
(0.036)\end{array}$ & $\begin{array}{c}0.026 \\
(0.036)\end{array}$ & $\begin{array}{l}-0.002 \\
(0.022)\end{array}$ & $\begin{array}{l}-0.014 \\
(0.021)\end{array}$ & $\begin{array}{l}-0.011 \\
(0.021)\end{array}$ & $\begin{array}{c}0.033 \\
(0.023)\end{array}$ & $\begin{array}{c}0.029 \\
(0.023)\end{array}$ & $\begin{array}{c}0.034 \\
(0.023)\end{array}$ & $\begin{array}{l}-0.042 \\
(0.045)\end{array}$ & $\begin{array}{l}-0.059 \\
(0.045)\end{array}$ & $\begin{array}{l}-0.041 \\
(0.045)\end{array}$ & $\begin{array}{l}0.070^{\dagger \dagger} \\
(0.027)\end{array}$ & $\begin{array}{l}0.081^{\dagger \dagger} \\
(0.027)\end{array}$ & $\begin{array}{l}0.073^{\dagger} \\
(0.027)\end{array}$ \\
\hline Brother present & $\begin{array}{c}0.313^{\dagger} \\
(0.163)\end{array}$ & - & - & $\begin{array}{c}0.119 \\
(0.161)\end{array}$ & - & - & $\begin{array}{c}0.269 \\
(0.209)\end{array}$ & - & - & $\begin{array}{c}0.065 \\
(0.171)\end{array}$ & - & - & $\begin{array}{c}0.247 \\
(0.201)\end{array}$ & - & - & $\begin{array}{c}-0.474^{\dagger} \\
(0.249)\end{array}$ & - & - \\
\hline Sister present & - & $\begin{array}{l}-0.059 \\
(0.160)\end{array}$ & - & - & $\begin{array}{l}-0.078 \\
(0.173)\end{array}$ & - & - & $\begin{array}{l}-0.280 \\
(0.204)\end{array}$ & - & - & $\begin{array}{l}-0.127 \\
(0.165)\end{array}$ & - & - & $\begin{array}{c}-0.252 \\
(0.188)\end{array}$ & - & - & $\begin{array}{c}0.190 \\
(0.242)\end{array}$ & - \\
\hline Proportion of Sisters & - & - & $\begin{array}{l}-0.297 \\
(0.300)\end{array}$ & - & - & $\begin{array}{l}-0.249 \\
(0.322)\end{array}$ & - & - & $\begin{array}{c}-0.810^{\dagger \dagger} \\
(0.361)\end{array}$ & - & - & $\begin{array}{c}-0.289 \\
(0.311)\end{array}$ & - & - & $\begin{array}{l}-0.538 \\
(0.376)\end{array}$ & - & - & $\begin{array}{l}0.707^{\dagger} \\
(0.424)\end{array}$ \\
\hline $\mathrm{R}^{2}$ & 0.265 & 0.263 & 0.263 & 0.680 & 0.679 & 0.680 & 0.109 & 0.109 & 0.114 & 0.210 & 0.210 & 0.210 & 0.663 & 0.664 & 0.664 & 0.105 & 0.099 & 0.103 \\
\hline Observations & & 1067 & & & 318 & & & 540 & & & 812 & & & 278 & & & 441 & \\
\hline
\end{tabular}




\section{Appendix Table 3: Sibling Sex Composition, Educational Attainment and Reference Group}

\begin{tabular}{|c|c|c|c|c|c|c|c|c|c|c|c|c|}
\hline & \multicolumn{6}{|c|}{ Male } & \multicolumn{6}{|c|}{ Female } \\
\hline & \multicolumn{2}{|c|}{ West German } & \multicolumn{2}{|c|}{ East German } & \multicolumn{2}{|c|}{ Foreign } & \multicolumn{2}{|c|}{ West German } & \multicolumn{2}{|c|}{ East German } & \multicolumn{2}{|c|}{ Foreign } \\
\hline & Children $=2$ & Children $>2$ & Children $=2$ & Children $>2$ & Children $=2$ & Children $>2$ & Children $=2$ & 2 Children $>2$ & 2 Children $=2$ & Children $>2$ & Children $=2$ & Children $>2$ \\
\hline \multirow[t]{2}{*}{ Constant } & $-7.786^{\dagger \dagger}$ & -1.441 & $-12.961^{\dagger \dagger}$ & $-9.725^{\dagger \dagger}$ & 2.180 & $3.758^{\dagger \dagger}$ & $-5.165^{\dagger \dagger}$ & 0.235 & $-11.367^{\dagger \dagger}$ & $-11.148^{\dagger \dagger}$ & 2.572 & $7.471^{\dagger \dagger}$ \\
\hline & $(2.064)$ & $(2.087)$ & $(1.629)$ & $(2.716)$ & $(3.380)$ & $(2.023)$ & $(2.331)$ & (1.997) & $(2.400)$ & $(3.003)$ & $(5.172)$ & $(2.406)$ \\
\hline \multirow[t]{2}{*}{ Mother Catholic } & $1.412^{\dagger \dagger}$ & $0.830^{\dagger \dagger}$ & -0.521 & 0.204 & 0.305 & 0.335 & $1.459^{\dagger \dagger}$ & $1.042^{\dagger \dagger}$ & 0.277 & 1.034 & -0.030 & 0.108 \\
\hline & $(0.273)$ & $(0.278)$ & $(0.413)$ & $(0.571)$ & $(0.337)$ & $(0.225)$ & $(0.302)$ & $(0.306)$ & $(0.575)$ & $(0.703)$ & $(0.435)$ & $(0.276)$ \\
\hline \multirow[t]{2}{*}{ Mother Protestant } & $1.503^{\dagger \dagger}$ & $0.821^{\dagger \dagger}$ & -0.054 & -0.156 & 1.348 & 0.886 & $1.261^{\dagger \dagger}$ & $0.885^{\dagger \dagger}$ & -0.105 & -0.066 & 0.836 & $3.842^{\dagger \dagger}$ \\
\hline & $(0.268)$ & $(0.274)$ & $(0.213)$ & $(0.330)$ & (1.391) & $(0.694)$ & $(0.292)$ & $(0.312)$ & $(0.244)$ & $(0.315)$ & $(1.375)$ & (1.019) \\
\hline \multirow{2}{*}{$\begin{array}{l}\text { Parent Died before } \\
\text { Age } 14\end{array}$} & 0.834 & 0.019 & 0.211 & -0.386 & -2.121 & -1.796 & 0.754 & -0.315 & -0.522 & 0.121 & -1.524 & -1.460 \\
\hline & $(0.919)$ & $(0.636)$ & (1.031) & $(0.666)$ & (1.533) & (1.899) & $(0.897)$ & $(0.675)$ & $(0.976)$ & $(0.690)$ & (1.773) & $(1.460)$ \\
\hline \multirow{2}{*}{$\begin{array}{l}\text { Mother's Years of } \\
\text { Schooling }\end{array}$} & $0.227^{\dagger \dagger}$ & $0.274^{\dagger \dagger}$ & $0.122^{\dagger \dagger}$ & -0.018 & 0.059 & 0.015 & 0.020 & $0.151^{\dagger \dagger}$ & -0.049 & -0.003 & 0.147 & 0.020 \\
\hline & $(0.058)$ & $(0.062)$ & $(0.060)$ & $(0.082)$ & $(0.088)$ & $(0.055)$ & $(0.068)$ & $(0.061)$ & $(0.067)$ & $(0.092)$ & (0.099) & $(0.075)$ \\
\hline \multirow{2}{*}{$\begin{array}{l}\text { Information on } \\
\text { Father Available }\end{array}$} & -0.311 & $0.780^{\dagger}$ & 0.062 & $1.316^{\dagger}$ & -0.088 & 0.429 & -0.934 & 0.797 & -0.301 & 0.739 & 1.067 & -1.002 \\
\hline & $(0.507)$ & $(0.437)$ & $(0.562)$ & $(0.749)$ & (1.240) & $(0.561)$ & $(0.568)$ & $(0.512)$ & $(0.596)$ & $(0.975)$ & (1.163) & $(0.710)$ \\
\hline \multirow{2}{*}{$\begin{array}{l}\text { Father's Years of } \\
\text { Schooling }\end{array}$} & 0.005 & -0.004 & 0.014 & -0.058 & -0.022 & 0.031 & $0.087^{\dagger \dagger}$ & -0.009 & 0.034 & 0.014 & -0.006 & $0.098^{\dagger \dagger}$ \\
\hline & $(0.028)$ & $(0.025)$ & $(0.037)$ & $(0.050)$ & $(0.060)$ & $(0.036)$ & $(0.032)$ & $(0.026)$ & $(0.033)$ & $(0.069)$ & $(0.061)$ & $(0.048)$ \\
\hline \multirow{2}{*}{$\begin{array}{l}\text { Father Skilled } \\
\text { Worker }\end{array}$} & $0.448^{\dagger \dagger}$ & 0.345 & -0.161 & $0.851^{\dagger \dagger}$ & 0.520 & 0.171 & 0.456 & -0.042 & -0.089 & 0.498 & 0.348 & 0.149 \\
\hline & $(0.230)$ & $(0.226)$ & $(0.211)$ & $(0.308)$ & $(0.386)$ & $(0.248)$ & $(0.240)$ & $(0.242)$ & $(0.284)$ & $(0.316)$ & $(0.551)$ & $(0.318)$ \\
\hline \multirow{2}{*}{$\begin{array}{l}\text { Father Worker: } \\
\text { Other }\end{array}$} & -0.316 & 0.148 & 0.252 & $1.071^{\dagger}$ & -0.357 & -0.158 & -0.191 & 0.002 & -0.142 & $1.168^{\dagger \dagger}$ & 0.313 & -0.539 \\
\hline & (0.317) & (0.299) & $(0.396)$ & $(0.580)$ & $(0.621)$ & $(0.277)$ & $(0.376)$ & $(0.314)$ & $(0.428)$ & $(0.496)$ & $(0.602)$ & $(0.331)$ \\
\hline \multirow{2}{*}{$\begin{array}{l}\text { Payments to } \\
\text { Parents }\end{array}$} & -0.139 & -0.484 & -0.284 & $-1.315^{\dagger \dagger}$ & $-2.425^{\dagger \dagger}$ & 1.411 & 0.168 & -0.675 & -0.417 & $2.281^{\dagger \dagger}$ & -0.255 & 0.782 \\
\hline & (0.949) & $(0.482)$ & $(0.935)$ & $(0.578)$ & (1.124) & $(0.933)$ & $(0.833)$ & $(0.634)$ & (1.187) & $(0.834)$ & $(0.935)$ & (1.162) \\
\hline \multirow[t]{2}{*}{ Age } & $0.936^{\dagger \dagger}$ & $0.566^{\dagger \dagger}$ & $1.355^{\dagger \dagger}$ & $1.153^{\dagger \dagger}$ & $0.428^{\dagger \dagger}$ & $0.307^{\dagger \dagger}$ & $0.936^{\dagger \dagger}$ & $0.355^{\dagger \dagger}$ & $1.385^{\dagger \dagger}$ & $1.206^{\dagger \dagger}$ & 0.235 & 0.173 \\
\hline & $(0.132)$ & $(0.120)$ & $(0.104)$ & $(0.149)$ & $(0.215)$ & $(0.134)$ & $(0.149)$ & $(0.123)$ & $(0.159)$ & $(0.166)$ & $(0.370)$ & $(0.152)$ \\
\hline \multirow[t]{2}{*}{$\mathrm{Age}^{2}$} & $-0.012^{\dagger \dagger}$ & $-0.007^{\dagger \dagger}$ & $-0.019^{\dagger \dagger}$ & $-0.016^{\dagger \dagger}$ & $-0.007^{\dagger \dagger}$ & -0.004 & $-0.013^{\dagger \dagger}$ & -0.003 & $-0.018^{\dagger \dagger}$ & $-0.017^{\dagger \dagger}$ & -0.002 & -0.002 \\
\hline & $(0.002)$ & $(0.002)$ & $(0.002)$ & $(0.003)$ & $(0.004)$ & $(0.002)$ & $(0.003)$ & $(0.002)$ & $(0.003)$ & $(0.003)$ & $(0.007)$ & $(0.003)$ \\
\hline
\end{tabular}


Table 3: Continued

\begin{tabular}{|c|c|c|c|c|c|c|c|c|c|c|c|c|}
\hline & & & & ale & & & & & Fen & nale & & \\
\hline & West & erman & East C & Ferman & & reign & West & German & East G & erman & For & eign \\
\hline & Children $=$ & Children $>2$ & Children $=2$ & Children $>$ & Children= & 2 Children> & 2 Children $=2$ & 2 Children $>2$ & 2 Children $=2$ & Children $>2$ & 2 Children $=2$ & Children $>2$ \\
\hline Birth Order & $\begin{array}{l}-0.233 \\
(0.293)\end{array}$ & $\begin{array}{c}0.042 \\
(0.104)\end{array}$ & $\begin{array}{l}-0.024 \\
(0.287)\end{array}$ & $\begin{array}{l}-0.115 \\
(0.139)\end{array}$ & $\begin{array}{c}0.661 \\
(0.486)\end{array}$ & $\begin{array}{c}0.135^{\dagger} \\
(0.082)\end{array}$ & $\begin{array}{l}-0.295 \\
(0.312)\end{array}$ & $\begin{array}{l}-0.144 \\
(0.122)\end{array}$ & $\begin{array}{l}-0.125 \\
(0.315)\end{array}$ & $\begin{array}{c}0.112 \\
(0.156)\end{array}$ & $\begin{array}{c}0.312 \\
(0.673)\end{array}$ & $\begin{array}{l}-0.029 \\
(0.107)\end{array}$ \\
\hline Birth Distance & $\begin{array}{c}0.023 \\
(0.050)\end{array}$ & $\begin{array}{c}0.009 \\
(0.041)\end{array}$ & $\begin{array}{c}0.013 \\
(0.049)\end{array}$ & $\begin{array}{l}0.143^{\dagger \dagger} \\
(0.049)\end{array}$ & $\begin{array}{c}0.066 \\
(0.095)\end{array}$ & $\begin{array}{c}0.039 \\
(0.043)\end{array}$ & $\begin{array}{l}-0.001 \\
(0.054)\end{array}$ & $\begin{array}{c}0.077^{\dagger} \\
(0.045)\end{array}$ & $\begin{array}{l}-0.032 \\
(0.046)\end{array}$ & $\begin{array}{c}0.030 \\
(0.066)\end{array}$ & $\begin{array}{c}0.010 \\
(0.152)\end{array}$ & $\begin{array}{c}0.041 \\
(0.054)\end{array}$ \\
\hline Number of Siblings & - & $\begin{array}{l}-1.229^{\dagger \dagger} \\
(0.292)\end{array}$ & - & $\begin{array}{c}0.338 \\
(0.597)\end{array}$ & - & $\begin{array}{l}-0.265 \\
(0.283)\end{array}$ & - & $\begin{array}{l}-0.013 \\
(0.323)\end{array}$ & - & $\begin{array}{c}0.382 \\
(0.681)\end{array}$ & - & $\begin{array}{l}-0.640^{\dagger} \\
(0.350)\end{array}$ \\
\hline $\begin{array}{l}\text { Number of } \\
\text { Siblings }^{2}\end{array}$ & - & $\begin{array}{l}0.099^{\dagger \dagger} \\
(0.031)\end{array}$ & - & $\begin{array}{l}-0.031 \\
(0.071)\end{array}$ & - & $\begin{array}{c}0.001 \\
(0.030)\end{array}$ & - & $\begin{array}{c}0.002 \\
(0.034)\end{array}$ & - & $\begin{array}{l}-0.069 \\
(0.084)\end{array}$ & - & $\begin{array}{c}0.063^{\dagger} \\
(0.038)\end{array}$ \\
\hline Only Brothers & - & $\begin{array}{l}-0.129 \\
(0.274)\end{array}$ & - & $\begin{array}{l}-0.083 \\
(0.451)\end{array}$ & - & $\begin{array}{c}0.307 \\
(0.267)\end{array}$ & - & $\begin{array}{c}0.311 \\
(0.275)\end{array}$ & - & $\begin{array}{c}0.339 \\
(0.352)\end{array}$ & - & $\begin{array}{c}0.199 \\
(0.326)\end{array}$ \\
\hline Only Sisters & $\begin{array}{l}-0.108 \\
(0.202)\end{array}$ & $\begin{array}{l}-0.719^{\dagger \dagger} \\
(0.297)\end{array}$ & $\begin{array}{l}-0.026 \\
(0.187)\end{array}$ & $\begin{array}{l}-0.142 \\
(0.316)\end{array}$ & $\begin{array}{l}-0.053 \\
(0.345)\end{array}$ & $\begin{array}{l}-0.332 \\
(0.291)\end{array}$ & $\begin{array}{c}0.110 \\
(0.217)\end{array}$ & $\begin{array}{l}-0.338 \\
(0.299)\end{array}$ & $\begin{array}{l}-0.289 \\
(0.230)\end{array}$ & $\begin{array}{c}0.222 \\
(0.518)\end{array}$ & $\begin{array}{c}0.396 \\
(0.418)\end{array}$ & $\begin{array}{c}0.575^{\dagger} \\
(0.346)\end{array}$ \\
\hline $\mathrm{R}^{2}$ & 0.307 & 0.215 & 0.715 & 0.626 & 0.117 & 0.111 & 0.237 & 0.201 & 0.677 & 0.663 & 0.060 & 0.068 \\
\hline Observations & 531 & 536 & 197 & 121 & 127 & 413 & 402 & 410 & 177 & 101 & 127 & 314 \\
\hline
\end{tabular}

